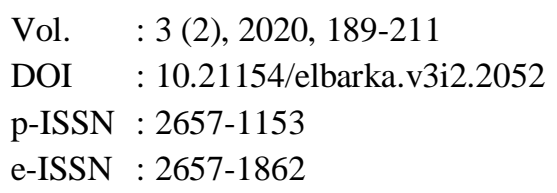

\title{
DAMPAK PENERAPAN AFCTA DI INDONESIA DALAM PERSPEKTIF IBNU KHALDUN DAN ABU UBAID
}

\author{
Nurul Anggesti, Mufti Afif \\ Universitas Darussalam Gontor, Indonesia \\ Email: nurulanggesti@gmail.com,muftiafif@unida.gontor.ac.id
}

\begin{abstract}
This study examines the impact of the application of the ACFTA trade cooperation on the economy in Indonesia in terms of the international trade theory of Ibn Khaldun and Abu Ubaid. The methods used is mixed methods (qualitative and quantitative methods) by analyzed the impact of ACFTA on Import and exports beetwen Indonesia and China using time series data during 2005-2018 were sourced from Central Bereau of Statistics and see the relevants thingking of Abu Ubaid dan Ibnu Khaldun to the implementation of ACFTA in Indonesia. The result showed that ACFTA has bad impact on the economy of Indonesia due to the zero cost of tariff on incoming goods. So, a new policy is needed as mentioned by the thingking of Abu Ubaid and Ibnu Khaldun. By eliminating the zero tariff policy and prioritizing economic succes based on the principle of justice and benefit of Indonesia.
\end{abstract}

Keywords: ACFTA, Ibn Khaldun, Abu Ubaid, China, tariff.

Abstrak: Penelitian ini mengkaji tentang dampak penerapan kerjasama dagang ACFTA terhadap perekonomian di Indonesia ditinjau dari teori perdagangan internasional Ibnu Khaldun dan Abu Ubaid. Metode yang digunakan adalah mixed methods (metode kualitatif dan metode kuantitatif), yaitu pertama, menganalisis dampak ACFTA terhadap ekspor Impor antara Indonesia dan China dengan menggunakan data time series dari tahun 2005-2018 yang didapat dari Badan Pusat Statisitk dan kedua, meninjau relevansi pemikiran Abu Ubaid dan Ibnu Khaldun terhadap penerapan ACFTA di Indonesia. 
Hasil penelitian menunjukkan bahwa selama ini ACFTA berdampak buruk bagi perekonomian Indonesia karena adanya biaya nol tarif terhadap barang yang masuk. Sehingga dibutuhkan kebijakan baru sebagaimana yang disebutkan oleh pemikiran dua tokoh ekonom muslim (Abu Ubaid dan Ibnu Khaldun) yaitu dengan menghilangkan kebijakan nol tarif yang kemudian mengutamakan keberhasilan ekonomi berdasarkan pada asas keadilan dan kemaslahatan masyarakat Indonesia.

Kata kunci: ACFTA, Ibnu Khaldun, Abu Ubaid, China, tarif

\section{PENDAHULUAN}

Perdagangan Internasional berarti terkait dengan transaksi jual beli barang atau jasa antar negara yang melintasi batas-batas suatu negara (Tabligh, 2016). Krugman dan Obstfeld menjelaskan bahwa terdapat dua alasan utama suatu negara melakukan perdagangan internasional. Pertama karena perbedaan sumber daya alam antara satu sama lain yang menjadikan peluang untuk mendapatkan keuntungan. Kedua adalah untuk mencapai skala ekonomis (economics of scale) dalam produksi (Soedijono, 2004). Sebelum teori perdagangan internasonal dikembangkan di Barat, Islam telah menerapkan konsepkonsep perdagangan internasional yaitu dibuktikan dalam QS. AlQuraisy (ayat 1-4) yang mengisahkan perdagangan penduduk Mekkah di negeri Syam dan Yaman. Adanya perdagangan internasional ini mendongkrak perekonomian nasional meningkat karena adanya kegiatan ekspor-impor barang yang dapat meningkatkan pendapatan masyarakat.

Di era perekonomian terbuka saat ini, meningkatnya nilai impor akan berdampak pada menurunnya PDB. Sehingga liberalisasi 
perdagangan suatu negara di satu sisi akan mendorong peningkatan nilai perdagangan, sedangkan disisi lain akan mempengaruhi neraca perdagangannya (Sabaruddin, 2015). Setelah perang dunia ke 2 peranan perdagangan internasional mengarah pada kebijakan perdagangan bebas. Hal tersebut ditandai dengan dibentuknya The General Agreement on tariffs and Trade (GATT), yaitu Kesepakatan internasional yang ditandatangani oleh Amerika Serikat dan 22 negara lain pada 1947 untuk mendorong liberalisasi perdagangan asing.

Liberalisasi perdagangan merupakan suatu kegiatan ekonomi yang memiliki peran strategis dalam upaya mempercepat pertumbuhan ekonomi dan pemerataan serta memberikan sumbangan dalam menciptakan lapangan pekerjaan. Perdagangan bebas juga dapat memberikan sejumlah manfaat seperti terbukanya akses pasar barang dan jasa, terpenuhinya bahan baku, bahan penolong dan barang modal, meningkatnya investasi yang dapat mempengaruhi struktur industri, mendorong adanya peningkatan kapasitas untuk meningkatkan daya saing industri domestik dan meningkatnya daya beli masyarakat. Namun, adanya perdagangan bebas tersebut tidak dapat memberikan manfaat yang besar jika daya saing industri-industri di dalam negeri jauh lebih rendah dibandingkan dengan luar negeri.

Salah satu negara yang menjadi kekuatan ekonomi dunia saat ini adalah Cina yang diikuti oleh dua negara Asia Timur lainnya yaitu Jepang dan Korea Selatan. Pada tahun 1953 kerjasama perdagangan antara Indonesia dan China telah dimulai dan berkembang pada tahun 2001 (Guilhot, 2010) dengan disepakatinya pelaksanaan kawasan perdagangan bebas antara negara anggota ASEAN dan China dengan 
mendeklarasikan perjanjian ASEAN free trade area atau disebut ACFTA (Syahidah, et.al, 2016). Dalam kerangka perjanjian tersebut, negara-negara yang menjadi anggota kesepakatan ACFTA saling memberikan preferential treatment pada tiga sektor yaitu sektor barang, sektor jasa dan sektor investasi. Preferential treatment merupakan perlakuan khusus yang lebih menguntungkan dibanding perlakuan yang diberikan kepada negara mitra dagang non anggota (Setiawan, 2012).

Kerjasama perdagangan bebas antara ASEAN dan China diatur dalam kesepakatan penurunan tarif dan kerjasama penghapusan tarif untuk mempermudah perdagangan internasional. Dengan adanya hal tersebut menjadikan harga barang impor dari Cina akan lebih murah karena tidak adanya tarif yang dibebankan atasnya. Barang-barang tersebut masuk ke pasar Indonesia dalam jumlah besar dan mempengaruhi tingkat harga produk dalam negeri (Indonesia). Hal ini diperparah dengan pola konsumsi masyarakat Indonesia yang lebih mencari barang murah (tidak memperhatikan asal/ nasionalisme dan komparasi kualitas), sehingga pasar produk lokal tersaingi oleh produk asal China (Salam \& Haryotejo, 2011).

Dalam sejarah ekonomi dunia muncul beberapa ekonom muslim yang turut membangun teori ekonomi/ konsep ekonomi Internasional diantaranya yaitu Ibnu Khaldun dan Abu Ubaid yang mana keduanya memiliki selisih periode sekitar $11 \mathrm{abad}$. Ibnu Khaldun berpendapat bahwa adanya perdagangan bebas merupakan tanda adanya kemajuan dalam negara. Hal ini disebabkan, apabila suatu negara ikut campur tangan dalam hal perdagangan maka akan 
mematikan perekonomian, meskipun dengan alasan untuk meningkatkan pendapatan negara (Huda, 2016). Namun Abu Ubaid berpendapat sebaliknya, perdagangan yang terlampau bebas (memberlakuan biaya nol tarif) dalam perdagangan internasional akan menghambat pertumbuhan ekonomi nasional, karena dalam Islam tidak ada konsep bebas dalam perdagangan, meskipun barang impor tersebut adalah barang milik kaum muslimin (Junaidi \& Muhaimin, 2017).

Ibnu Khaldun dinobatkan sebagai bapak ekonomi modern dengan konsep dasar ekonomi yang ditulis dalam karyanya yaitu Kitab Mukaddimah. Dalam kitab tersebut di bagi menjadi enam pasal (Khaldun, 2001). Ibn Khaldun memaparkan pemikiran ekonomi teori tentang pajak dan pengaruhn ya terhadap negara, teori harga di kota yang berhubungan dengan teori mekanisme pasar, penjelasan mengenai hakekat rezeki dan hasil usaha manusia, dilanjutkan dengan teori produksi, organisasi, teori tentang nilai, uang, gaji, laba dan keseimbangan pasar.

Sedangkan, Abu Ubaid merupakan salah satu tokoh muslim klasik yang karyanya (Kitab Al Amwal) banyak dirujuk oleh ekonom modern khususnya bidang ekonomi publik, dengan titik berat kajiannya tentang pengenaan pajak, undang-undang pertanahan, hukum administratif dan hukum internasional yang telah dipraktekkan pada masa Rasulullah saw, Khulafaurrasyidin terutama masa Umar bin Khattab dan Umar bin Abdul Aziz. Abu Ubaid yang merupakan salah seorang tokoh Islam membagi tiga bagian mengenai ekspor dan impor yaitu tidak adanya kebijakan nol tarif dalam perdagangan 
internasional, cukai bahan makanan pokok dibebankan lebih murah dan ada batas tertentu untuk dikenakan cukai (Al-Qasim, 1998).

Dengan berkembangnya pola perdagangan Indonesia dengan China dalam organisasi ACFTA (ASEAN China Free Trade Area) dewasa ini, penulis tertarik untuk mengkaji posisi Indonesia dalam organisasi dagang ACFTA serta pengaruh ACFTA terhadap perekonomian Indonesia. Juga melihat bagaimana pemikiran tokoh ekonomi Islam (Abu Ubaid dan Ibnu Khaldun) mengenai kerjasama dagang ACFTA tersebut.

\section{TINJAUAN LITERATUR}

\section{Biografi Ibnu Khaldun dan Abu Ubaid}

Ibnu Khaldun memiliki nama lengkap Abdurrahman Abu Zaid Waliuddin Ibn Khaldun, beliau lahir di Tunisia pada awal Ramadhan $732 \mathrm{H}$ atau bertepatan dengan 27 Mei $1332 \mathrm{M}$ (khaldun, 2001). Ibnu Khaldun menimba ilmu pertama kali kepada ayahnya. Dari kecil, ia sudah menghafal Al Qur'an dan menguasai tajwid (Qadariyah, 2016). Selain itu, ia juga mempelajari ilmu agama, fisika dan matematika dari beberapa ulama Andalusia yang hijrah ke Tunisia dan mendapatkan nilai yang memuaskan dari studinya tersebut. Ibnu Khaldun dikenal sebagai cendikiawan yang rajin menulis, bahkan ketika memasuki usia remaja karya-karya tulisnya sudah tersebar. Tulisan-tulisan dan pemikiran Ibnu Khaldun dilatarbelakangi oleh ketekunan serta pendalaman kajian pada masa studinya, ditambah dengan kebiasaan mengamati kehidupan berbagai sosioal masyarakat yang dipadukan 
dengan pengetahuannya yang luas, kemudian didukung oleh kehidupannya yang selalu mengembara dari satu daerah ke daerah lain.

Abu Ubaid memiliki nama lengkap al-Qasim bin Sallam bin Miskin bin Zaid al-Harawi al-Azadi al-Baghdadi, lahir di kota Hirrah Khurasan sebelah barat laut Afghanistan pada 154 H (Qadariyah, 2016). Abu Ubaid hidup pada masa kekhalifahan Daulah Abbasiyah yaitu pada masa khalifah al-Mahdi (158 H/ 775 M). Pada 192 H, Gubernur Thugur di masa khalifah Harun Ar Rasyid, Tsabit ibn Nashir ibn Malik mengangkat Abu Ubaid sebagai qadhi (hakim) di Tarsus hingga $210 \mathrm{H}$. Kemudian Abu Ubaid tinggal di Baghdad selama 10 tahun dan pada $219 \mathrm{H}$ setelah berhaji ia tinggal di Mekah hingga wafat. Abu Ubaid meninggal pada $224 \mathrm{H}$ (Wally, 2018).

\section{Asean China Free Trade Area}

Menurut Departemen Keuangan RI, ACFTA adalah kesepakatan dari negara-negara ASEAN untuk membentuk kawasan perdagangan bebas dengan negara China (Endraswati, 2012) yang menghilangkan atau mengurangi segala bentuk hambatan perdagangan baik tarif maupun non tarif, peningkatan akses pasar jasa, peraturan dan ketentuan investasi, peningkatan integrasi ekonomi, serta mengurangi kesenjangan pembangunan diantara negara anggotanya (Meranti, 2017). Secara kronologis pembuatan perjanjian internasional seperti ACFTA melalui prosedur yaitu; perundingan (negotiation), penandanganan (signature), ratification (ratifikasi) dan keberlakuan; penundaan dan pengunduran dari ACFTA (Sheng, et.al, 2012). 
Adapun tujuan dari dibentuknya AFCTA adalah (1) memperkuat dan meningkatkan kerjasama perdagangan kedua belah pihak; (2) meliberalisasikan perdagangan barang dan jasa melalui pengurangan atau penghapusan tarif; (3) mencari area baru dan mengembangkan kerjasama ekonomi yang saling menguntungkan kedua pihak; (4) memfasilitasi integrasi ekonomi yang lebih efektif dengan negara anggota baru ASEAN dan menjembatani Gap yang ada di kedua belah pihak (Sinaga, 2010). Untuk melaksanakan ACFTA, terdapat tiga tahap proses penurunan tarif yaitu The Early Harvest Programme (EHP), jalur normal (normal track) yang terbagi menjadi dua yaitu Normal Track 1 dan Normal Track 2 dan jalur sensitif (Sensitive Track) yang terbagi menjadi 2 skema yaitu Sensitive List dan Highly Sensitive List.

Dalam kegiatan ekspor impor antar negara atau arus masuk dan keluar dikenal dengan istilah neraca perdagangan. Neraca perdagangan adalah suatu catatan aliran keuangan yang menunjukkan nilai transaksi perdagangan dan aliran dana yang dilakukan antara satu negara dengan negara lain dalam suatu tahun tertentu (Sukirno, 2015). Neraca perdagangan memperlihatkan selisih antar nilai ekspor dan nilai impor (Nopirin, 2013). Transaksi ini meliputi hasil-hasil sektor pertanian, barang-barang produksi industri dan neraca (perbedaan antara ekspor dan impor). Jika nilai impor lebih kecil dari pada nilai ekspor maka neraca perdagangan dinyatakan positif (atau surplus). Namun kebalikannya, jika nilai impor lebih besar dari pada nilai ekspor maka neraca perdagangan dinyatakan negatif (atau defisit) yang berarti 
negara tersebut memiliki banyak hutang luar negeri (Machmud, 2016). Berikut Jumlah Ekspor-Impor Indonesia-China tahun 2005-2018:

Gambar 1.

Jumlah Ekspor-Impor Indonesia-China tahun 2005-2018

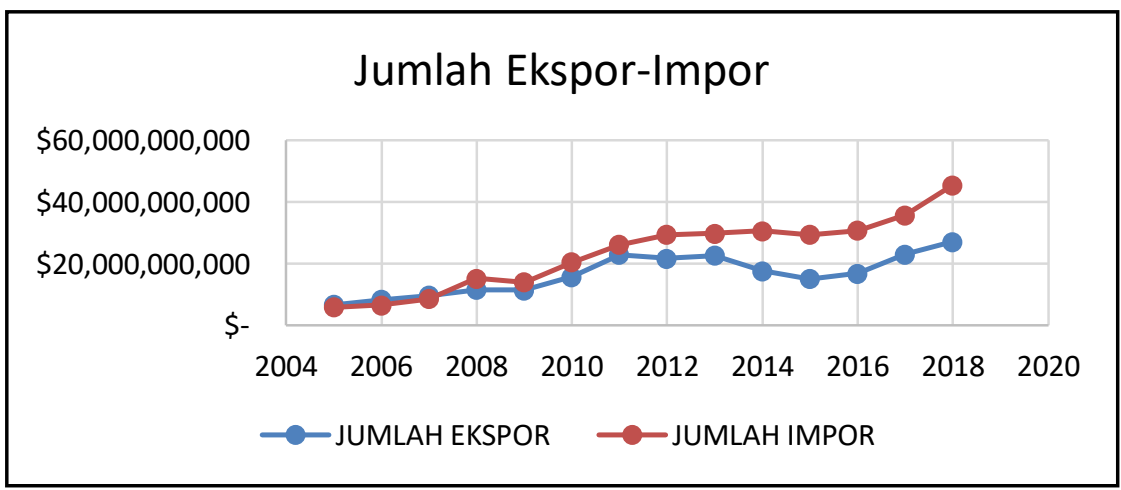

Sumber: Data Badan Pusat Statistik (BPS) setelah diolah

\section{METODE PENELITIAN}

Penelitian ini menggunakan pendekatan metode gabungan antara kualitatif dan kuantitatif atau disebut mixed method (Sugiono, 2016). Mix method digunakan untuk mengurangi terjadinya bias yang terdapat pada satu pendekatan metode, sehingga perlu diperkuat dan diperjelas melalui informasi-informasi yang diperoleh dari pendekatan metode lainnya. Dengan demikian nantinya diharapkan hasil yang didapatkan dari proses penelitian mendekati kondisi yang sebenarnya. Metode kualitatif dilakukan melalui library reaseach yaitu menganalisis ide dan pemikiran tokoh (Ibnu Khaldun dan Abu Ubaid) dari data primer yang berupa karya buku atau karya tulis lainnya yang pernah dibuatnya tentu dalam konteks penelitian ini adalah gagasan/ ide dan pemikirannya terkait perdagangan bebas. Sedangkan metode kuantitatif yaitu dengan menganalisis pengaruh ACFTA terhadap 
ekspor impor antara Indonesia dan China dengan data time series 2005-2018 yang dilakukan dengan uji wilcoxon signed ranks test.

\section{HASIL DAN PEMBAHASAN}

\section{Uji Normalitas}

Tabel 1: Hasil Uji Normalitas Ekspor

\begin{tabular}{ccccc}
\hline \multicolumn{5}{c}{ Kolmogorov-Smirnov } \\
\hline & Statistic & Df & Sig & Keterangan \\
Ekspor Sebelum ACFTA & 0,171 & 84 & 0,000 & Tidak Normal \\
Ekspor Sesudah ACFTA & 0,096 & 84 & 0,055 & Normal \\
\hline
\end{tabular}

Tabel 2. Hasil Uji Normalitas Impor

\begin{tabular}{ccccc}
\hline \multicolumn{4}{c}{ Kolmogorov-Smirnov } \\
\hline & Statistic & Df & Sig & Keterangan \\
Impor Sebelum ACFTA & 0,143 & 84 & 0,000 & Tidak Normal \\
Impor Sesudah ACFTA & 0,154 & 84 & 0,000 & Tidak Normal \\
\hline
\end{tabular}

Setelah melakukan uji normalitas, hasil uji menunjukkan bahwa data ekspor dan data impor berdistribusi tidak normal. Untuk hasil uji normalitas ekspor sebelum ACFTA dengan nilai signifikansinya adalah $0,000<0,05$ dan nilai signifikansi setelah ACFTA yaitu 0,055 $>0,05$. Hal ini menunjukkan bahwa data ekspor yang dilakukan sebelum dan setelah diterapkannya ACFTA menunjukkan data yang berdistribusi tidak normal. Sedangkan untuk hasil uji normalitas impor menunjukkan nilai signifikansi impor sebelum ACFTA $0,000<0,05$ dan nilai signifikansi setelah ACFTA $0,000<0,05$. Berdasarkan hasil uji normalitas yang menunjukkan data yang berdistribusi tidak normal maka uji hipotesis yang digunakan untuk menganalis ekspor dan impor menggunakan uji non parametrik yaitu Wilcoxon signed rank test. Uji 
tersebut dilakukan dengan menggunakan aplikasi Statistical Package for the Social Sciences (SPSS) versi 20.

\section{Uji Wilcoxon Signed Ranks Test pada Ekspor}

Tabel 3: Hasil Pertama Wilcoxon Signed Ranks Test Ekspor Descriptive Satitstics

\begin{tabular}{cccccc}
\hline & N & Minimum & Maximum & Mean & $\begin{array}{c}\text { Std } \\
\text { Deviation }\end{array}$ \\
\hline EKSPOR SBL & 84 & 384015313 & 2430216097 & 1029177201 & 484314590.9 \\
EKSPOR SSD & 84 & 103644815 & 2581219301 & 1713327318 & 416832697.7 \\
$\quad \begin{array}{c}\text { Valid N } \\
\text { (listwise) }\end{array}$ & 84 & 2 & & & \\
\hline
\end{tabular}

Output pertama adalah Descriptive Statistics yang menunjukkan nilai Mean, standar deviasi, minimum dan maksimum dari masing-masing kelompok data. Dari output diatas dapat disimpulkan bahwa rata-rata nilai ekspor setelah penerapan ACFTA meningkat dari sebelum penerapan ACFTA.

Tabel 4: Hasil Kedua Wilcoxon Signed Ranks Test Ekspor Ranks

\begin{tabular}{llrrr}
\hline & & $\mathrm{N}$ & Mean Rank & Sum Ranks \\
\hline EKSPOR & Negative Ranks & $3^{\mathrm{a}}$ & 5.67 & 17.00 \\
SSD - & Positive Ranks & $81^{\mathrm{b}}$ & 43.86 & 3553.00 \\
EKPSOR & Ties & $0^{\mathrm{c}}$ & & \\
SBL & Total & 84 & & \\
& & & \\
\hline
\end{tabular}

a. EKSPOR SSD < EKSPOR SBL

b. EKSPOR SSD $>$ EKSPOR SBL

c. EKSPOR SSD $=$ EKSPOR SBL

Output kedua yaitu Ranks, dilihat dari nilai mean rank dan sum of ranks dari kelompok negative ranks, positive ranks dan ties. Dapat dilihat bahwa terdapat 3 negative ranks yang berarti terdapat 3 nilai ekspor sesudah ACFTA yang lebih kecil dari nilai ekspor sebelum 
ACFTA, sedangkan 81 lainnya memiliki nilai yang lebih besar. Hal ini menunjukkan bahwa nilai ekspor setelah ACFTA mengalami peningkatan.

Tabel 5: Hasil Ketiga Wilcoxon Signed Ranks Test Ekspor

\begin{tabular}{lr}
\hline \multicolumn{2}{c}{ EKSPOR SSD - EKSPOR SBL } \\
\hline $\mathrm{Z}$ & $-7.885^{\mathrm{b}}$ \\
Asymp. Sig. & .000 \\
(2-tailed) & \\
\hline a. Wilcoxon Signed Ranks Test & \\
b. & Based on negative ranks
\end{tabular}

Pada output ketiga yaitu Test Statistic, dapat dilihat bahwa nilai Z adalah sebesar -7,885 dengan sig. 0,000. Penelitian ini menggunakan taraf nyata $5 \%$ sehingga batas penelitiannya adalah 0,05 . Dilihat dari prob atau sig $(0,000)<(0,05)$ maka $\mathrm{H}_{\mathrm{o}}$ ditolak dan $\mathrm{H}_{1}$ diterima yaitu ada perbedaan antara nilai ekspor sebelum dan setelah diterapkannya ACFTA. Dapat disimpulkan bahwa ACFTA berpengaruh secara signifikan dalam meningkatkan ekspor.

\section{Uji Wilcoxon Signed Ranks Test pada Impor}

Tabel 6: Hasil Pertama Wilcoxon Signed Ranks Test Import Descriptive Satitstics

\begin{tabular}{cccccc}
\hline & $\mathrm{N}$ & Minimum & Maximum & Mean & $\begin{array}{c}\text { Std } \\
\text { Deviation }\end{array}$ \\
\hline IMPOR SBL & 84 & 374126476 & 2506283324 & 1153849759 & 618182782.8 \\
IMPOR SSD & 84 & 1825413313 & 4499823830 & 2754486809 & 609143352.7 \\
$\begin{array}{c}\text { Valid N } \\
\text { (listwise) }\end{array}$ & 84 & & & & \\
\hline
\end{tabular}

Output pertama adalah Descriptive Statistics yang menunjukkan nilai rata-rata, standar deviasi, minimum dan maksimum dari masingmasing kelompok data. Dari output data di atas dapat disimpulkan 
bahwa rata-rata nilai impor setelah penerapan ACFTA meningkat dari sebelum penerapan ACFTA.

Tabel 7: Hasil Kedua Wilcoxon Signed Ranks Test Import Ranks

\begin{tabular}{llrrr}
\hline & & N & Mean Rank & Sum Ranks \\
\hline IMPOR SSD - & Negative Ranks & $1^{\mathrm{a}}$ & 2.00 & 2.00 \\
IMPOR SBL & Positive Ranks & $83^{\mathrm{b}}$ & 42.99 & 3568.00 \\
& Ties & $0^{\mathrm{c}}$ & & \\
& Total & 84 & & \\
\hline
\end{tabular}

a. IMPOR SSD < IMPOR SBL

b. IMPOR SSD $>$ IMPOR SBL

c. $I M P O R$ SSD $=$ IMPOR SBL

Output kedua yaitu Ranks, dilihat dari nilai mean rank dan sum of ranks dari kelompok negative ranks, positive ranks dan ties. Dapat dilihat bahwa terdapat 1 negative ranks yang berarti terdapat 1 nilai impor sesudah ACFTA yang lebih kecil dari nilai impor sebelum ACFTA, sedangkan 83 lainnya memiliki nilai yang lebih besar. Hal ini menunjukkan bahwa nilai impor setelah ACFTA mengalami peningkatan.

Tabel 8: Hasil Ketiga Wilcoxon Signed Ranks Test Import IMPOR SSD -IMPOR SBL

\begin{tabular}{lr}
\hline $\mathrm{Z}$ & $-7.952^{\mathrm{b}}$ \\
$\begin{array}{l}\text { Asymp. Sig. (2- } \\
\text { tailed) }\end{array}$ & .000 \\
\hline
\end{tabular}
a. Wilcoxon Signed Ranks Test
b. Based on negative ranks

Berdasarkan output "test statistic”, diketahui bahwa nilai Z sebesar 7,952 dengan Asymp sig. (2 tailed) bernilai 0,000. Penelitian ini menggunakan taraf nyata 5\% sehingga batas kritis penelitiannya adalah 0,05 . Jika melihat prob atau sig. $(0,000)<(0,05)$ maka dapat 
disimpulkan bahwa "Hipotesis diterima". Artinya bahwa terdapat perbedaan antara nilai Impor sebelum dan setelah diterapkannya ACFTA, sehingga dapat disimpulkan bahwa ACFTA berpengaruh secara signifikan dalam meningkatkan impor.

\section{Ekspor Impor Indonesia ke China Sebelum dan Setelah Diterapkan ACFTA}

Berdasarkan hasil perhitungan statistik, diketahui bahwa nilai ekspor setelah diterapkannya ACFTA terdapat peningkatan dibandingkan sebelum diterapkannya ACFTA. Hasil analisis juga menunjukkan bahwa $\mathrm{H}_{0}$ ditolak dan $\mathrm{H}_{1}$ diterima yang berarti terdapat perbedaan antara nilai ekspor sebelum dan setelah diterapkannya ACFTA. Berdasarkan analisis Sig < taraf nyata yang berarti bahwa ACFTA memiliki pengaruh yang signifikan dalam meningkatkan ekspor.

Berdasarkan hasil perhitungan statistik, diketahui bahwa nilai impor setelah diterapkannya ACFTA terjadi peningkatan dibandingkan sebelum diterapkannya ACFTA. Hasil analisis juga menunjukkan bahwa $\mathrm{H}_{0}$ ditolak dan $\mathrm{H}_{1}$ diterima yang berarti terdapat perbedaan antara nilai impor sebelum dan setelah diterapkannya ACFTA. Berdasarkan analisis Sig < taraf nyata yang berarti bahwa ACFTA memiliki pengaruh yang signifikan dalam meningkatkan impor.

Jika dilihat dari hasil melalui uji Wilcoxon Signed Rank Test, menunjukkan bahwa nilai ekspor dan nilai impor Indonesia dengan China mengalami peningkatan. Meskipun demikian, peningkatan yang terjadi lebih di dominasi oleh aktifitas impor dari pada ekspor. Hal ini 
berarti neraca perdagangan Indonesia mengalami defisit. Hal ini di tunjukkan dengan data di bawah ini.

Tabel 9: Neraca Perdagangan Indonesia dan China

Tahun Jumlah Ekspor Jumlah Impor Selisih

\begin{tabular}{llrrrrc}
\hline 2005 & $\$ 6.662 .353 .805$ & $\$$ & 5.842 .862 .513 & $\$$ & 819.491 .292 \\
2006 & $\$ 8.343 .571 .337$ & $\$$ & 6.636 .895 .111 & $\$$ & 1.706 .676 .226 \\
2007 & $\$ 9.675 .512 .723$ & $\$$ & 8.557 .877 .121 & $\$$ & 1.117 .635 .602 \\
2008 & $\$ 11.636 .503 .721$ & $\$$ & 15.247 .168 .927 & $\$$ & -3.610 .665 .206 \\
2009 & $\$ 11.499 .327 .261$ & $\$$ & 14.002 .170 .505 & $\$$ & -2.502 .843 .244 \\
2010 & $\$ 15.692 .611 .103$ & $\$$ & 20.424 .218 .244 & $\$$ & -4.731 .607 .141 \\
2011 & $\$ 22.941 .004 .929$ & $\$ 26.212 .187 .363$ & $\$$ & -3.271 .182 .434 \\
2012 & $\$ 21.659 .502 .652$ & $\$ 29.387 .074 .068$ & $\$$ & -7.727 .571 .416 \\
2013 & $\$ 22.601 .487 .232$ & $\$ 29.849 .464 .777$ & $\$$ & -7.247 .977 .545 \\
2014 & $\$ 17.605 .944 .452$ & $\$ 30.624 .339 .083$ & $\$$ & -13.018 .394 .631 \\
2015 & $\$ 15.046 .433 .777$ & $\$ 29.410 .887 .144$ & $\$$ & -14.364 .453 .367 \\
2016 & $\$ 16.790 .801 .287$ & $\$ 30.800 .462 .250$ & $\$$ & -14.009 .660 .963 \\
2017 & $\$ 23.083 .091 .196$ & $\$ 35.766 .832 .326$ & $\$$ & -12.683 .741 .130 \\
2018 & $\$ 27.132 .234 .095$ & $\$ 45.537 .832 .338$ & $\$$ & -18.405 .598 .243 \\
\hline
\end{tabular}

Data di atas menunjukkan bahwasanya jumlah ekspor yang meningkat dan jumlah impor juga meningkat. Namun peningkatan yang terjadi cenderung lebih besar dari sisi impor yang menyebabkan neraca perdagangan Indonesia mengalami defisit dibandingkan dengan China. Dengan kata lain bahwa China lebih banyak mengekspor barang ke Indonesia dibanding mengimpor barang dari Indonesia.

Jika dilihat dari neraca perdagangan antara Indonesia dan China dapat dinyatakan bahwa Indonesia belum bisa mendapatkan manfaat yang optimal dari adanya perjanjian perdagangan bebas ACFTA (ASEAN China Free Trade Area) dibandingkan negara China. 
Tingginya nilai ekspor China ke Indonesia dan konsistensi kenaikan ekspor tersebut menunjukkan bahwa China memiliki daya produksi yang tinggi. Dengan adanya perdagangan bebas ACFTA ini akan memudahkan masuknya produk China ke Indonesia karena berkurangnya bea masuk dan biaya lainnya.

\section{Dampak Penerapan ACFTA di Indonesia dalam Perspektif Ibnu Khaldun dan Abu Ubaid}

Ibnu Khaldun sangat mendukung adanya perdagangan bebas yang diberlakukan suatu negara, karena adanya perdagangan bebas menunjukkan kemajuan dalam negara tersebut. Namun, perdagangan bebas disini bukan berarti menghapuskan peranan pajak (Pertaminawati, 2016). Ibnu Khaldun berpendapat bahwa adanya pajak merupakan kebutuhan negara dalam hal pembangunan. Pajak yang dibebankan disini berdasarkan pada asas keadilan. Pajak yang dipungut tidak terlalu tinggi karena akan menjadi beban bagi masyarakat. Dengan adanya pajak, maka akan memberikan dampak terhadap kemakmuran baik rakyat maupun pemerintah.

Selain itu, adanya perdagangan bebas disini juga harus dibarengi dengan kualitas Sumber Daya Manusia (SDM) yang tinggi pula. Hal ini dapat dilakukan dengan meningkatkan mutu pendidikan yang ada di masyarakat. Jika kualitas SDM baik, maka adanya perdagangan bebas akan menjadi peluang yang besar dalam meningkatkan perekonomian negara. Namun, jika kualitas SDM tidak siap dalam menghadapi perdagangan bebas, maka akan menjadi bumerang sehingga perekonomian menjadi menurun. 
Jika dikaitkan antara pemikiran Ibnu Khaldun dengan penerapan ACFTA yang ada di Indonesia maka dapat dikatakan bahwa kerjasama dagang yang dilakukan Indonesia dengan China disini merugikan Indonesia karena ditiadakannya peranan pajak. Serta Indonesia yang belum mampu bersaing dengan negara China dalam hal produksi barang. Produksi barang dalam suatu negara juga dipengaruhi oleh kualitas Sumber Daya Manusia (SDM). Hal ini menjadikan neraca perdagangan Indonesia defisit dan menjadi mengalami kerugian.

Abu Ubaid berpendapat bahwa dalam perdagangan internasional meliputi di dalamnya tarif (artinya tidak ada biaya nol tarif), cukai bahan pokok dan ada batas tertentu untuk cukai. Hal ini berarti bahwa dalam transaksi perdagangan antar negara harus terdapat tarif yang diberlakukan. Namun terdapat pengecualian untuk tarif pada bahan pokok seperti gandum, beras dan lain-lain (Rizal, 2018). Hal ini dilakukan supaya banyak persediaan bahan pokok makanan yang datang sebagaimana kebutuhan utama masyarakat untuk mencapai kesejahteraan (Nugroho, 2018). Selain itu, dalam pemungutan tarif masuk terdapat batas yang ditentukan. Jika kurang dari batas tertentu tersebut, maka cukai tidak akan dipungut. Artinya penetapan tarif harus diberlakukan.

Dari pemikiran kedua ekonom muslim tersebut, baik Ibnu Khaldun maupun Abu Ubaid menjadikan asas keadilan atau sebagai landasan dalam perdagangan internsional. Yang mana keduanya sepakat dengan adanya perdagangan bebas, akan tetapi perdagangan bebas tersebut bukan berarti barang dagangan dapat keluar dan masuk 
begitu saja, atau dengan kata lain tidak memperbolehkan adanya tarif barrier pada suatu negara.

Sehingga perdagangan internasional yang dinyatakan Ibnu Khaldun dan Abu Ubaid masih relevan diterapkan hingga saat ini yaitu dengan menerapkan adanya tarif terhadap produk luar negeri yang masuk ke dalam negeri. Jika barang yang masuk dari luar negeri tidak dikenakan tarif atau dengan kata lain tarifnya adalah nol persen, maka harga barang asing tersebut di dalam negeri akan menjadi rendah dan akan bersaing ketat dengan produk dalam negeri, akhirnya permintaan barang luar akan banyak. Apabila barang-barang dalam negeri kalah bersaing, maka banyak industri dalam negeri yang gulung tikar tidak berproduksi dan akan memberhentikan banyak tenaga kerja (warga dalam negeri). Namun sebaliknya, jika barang dari luar negeri tersebut dikenakan tarif, maka harga jualnya akan meningkat sehingga konsumsi masyarakat akan barang tersebut akan berkurang.

Jika dikaitkan antara pemikiran Ibnu Khaldun dan Abu Ubaid dengan penerapan ACFTA di Indonesia, maka dapat dilihat bahwasanya adanya ACFTA tidak sejalan dengan pemikiran Ibnu Khaldun dan Abu Ubaid, sehingga yang terjadi adalah ACFTA memiliki dampak negatif bagi perekonomian Indonesia. Hal ini terlihat dari neraca perdagangan antara Indonesia dan China yang menunjukkan Indonesia lebih dirugikan dengan penerapan ACFTA karena nilai ekspor Indonesia ke China lebih kecil dibandingkan nilai impor Indonesia dari China. Sebab utama dari pada kerugian Indonesia dengan perjanjian ACFTA tersebut adalah karena adanya penghapusan tarif terhadap komoditi yang masuk ke dalam negeri. Sebagaimana 
yang diterapkan dalam ACFTA pada tahun 2012 yang telah memberlakukan tarif $0 \%$ untuk seluruh produk pada tahap EHP dan Normal track.

Pemberlakuan tarif $0 \%$ ini akan berdampak buruk bagi perekonomian Indonesia (Nasruddin, et.al, 2015), belum lagi jika melihat kualitas tenaga kerja yang ada di Indonesia. Jika dilihat dari sisi kualitas tenaga kerja di Indonesia masih kalah saing dengan negara-negara lain. Hal ini dibuktikan dari angka yang termaktub dalam Indeks Pembangunan Ketenagakerjaan (IPK) Indonesia yang menunjukkan bahwa Indonesia masih tergolong menengah ke bawah, meskipun secara nominal meningkat dari tahun 2018 sebesar 60,81 menjadi 61,06 pada 2019 (Hartanto, 2019). Maka di sini, Indonesia perlu mempertimbangkan lagi terkait pembebasan tarif dalam ACFTA, serta diperlukan peningkatan kualitas tenaga kerja Indonesia. Yang mana kualitas tenaga kerja Indonesia sangat mempengaruhi output berupa kualitas produk barang atau jasa yang akan dikonsumsi oleh masyarakat.

Sebenarnya keikutsertaan Indonesia dalam kerjasama ACFTA merupakan peluang untuk meningkatkan perekonomian yaitu bisa menciptakan pasar yang lebih luas. Namun, jika perjanjian perdagangan tersebut ditujukan untuk pembebasan tarif terhadap barang dan jasa negara-negara luar ke dalam negeri, maka akan berdampak negatif bagi perekonomian Indonesia. 


\section{KESIMPULAN}

Menurut pandangan Abu Ubaid dan Ibnu Khaldun, perdagangan bebas harus dilandasi dengan asas keadilan. Namun adanya ACFTA saat ini dinilai belum adil dalam hal perekonomian karena hanya menguntungkan satu pihak yaitu China dan merugikan pihak lain yaitu ASEAN, khususnya Indonesia. Perdagangan bebas disini bukan berarti menghapuskan tarif yang ada sehingga negara tidak memiliki pemasukan darinya, akan tetapi penerapan tarif dilakukan dengan kadar yang tidak terlalu besar sehingga tidak membebankan pihak terkait dan Negara tetap memiliki pendapatan. Selain itu, Ibnu Khaldun berpendapat agar perdagangan berjalan sesuai dengan yang direncanakan, maka dibutuhkan kualitas tenaga kerja yang tinggi pula.

Berdasarkan nilai ekspor impor selama tahun 2005 hingga 2018, menunjukkan bahwa nilai ekspor dan nilai impor Indonesia dengan China secara umum meningkat. Namun peningkatan yang terjadi lebih didominasi oleh impor yang lebih tinggi dibandingkan ekspornya. Hal ini berarti neraca perdagangan Indonesia mengalami defisit dibandingkan China. Oleh sebab itu dapat dinyatakan bahwa keikutsertaan Indonesia dalam kerangka kerjasama ACFTA ini tidak menguntungkan perekonomian Indonesia. Sehingga perlu dikaji ulang penerapan kerjasama tersebut supaya kerugian yang muncul dapat diantisipasi.

Dampak negatif kebijakan biaya nol tarif akan mengundang banjirnya produk barang luar negeri di Indonesia dan jika barang tersebut memiliki kualitas yang baik (minimal sama dengan kualitas 
dalam negeri) maka akan menyaingi produk masyarakat dalam negeri. Belum lagi jika dilihat dari aspek kualitas tenaga kerja Indonesia yang masih jauh lebih rendah dibandingkan dengan negara-negara lain. Tentunya hal ini akan menjadi kendala bagi kemajuan perekonomian Indonesia. Untuk itu pemerintah harus berupaya lebih keras lagi untuk menyadarkan gerenasi muda untuk bersama-sama meningkatkan pemahaman kondisi perekonomian dengan segala sebab permasalahannya, supaya kesadaran akan kualitas tenaga kerja dapat dipersiapkan sejak dini sebagai modal awal untuk meningkatkan produk dan jasa dalam negeri. Dengan demikian keikutsertaan Indonesia dalam ACFTA ini akan mengambil peran yang positif dan dapat mencapai tujuan kemajuan perekonomian Indonesia.

\section{REFERENSI}

Abu Ubaid Al Qasim. (1998). Al Amwal, Beirut: Dar Al-Fikr

Christin Sinaga, Lidya. (2010). Indonesia di tengah kesepakatan ACFTA, Jurnal Penelitian Politik, vol. 7, No. 2

Danis Ikhawan Meranti, Inud, (2012) Implikasi kerjasama ASEANChina Free Trade Arean (ACFTA) terhadap kinerja UMKM dan kesejahteraan pelaku UMKM di kabupaten Banyuwangi, Prodising Seminar Nasional \& Temu Ilmiah Jaringan Peneliti

Endraswati, Hikmah, Biaya Produksi Islami: Alternatif Solusi bagi UKM menghadapi era ACFTA

Guilhot, Laetitia. (2010). Assesing the Impact of the main East Asian Free Trade Agreements Using a Gravity Model, Economic Bulletin, Volume 30, Issue 1

Huda, Nurul. (2016). Epistemologi Pemikiran Ekonomi Ibnu Khaldun, Proceeding of International Conference On Islamic Epistemology, ISBN: 978-602-361-048-8 
Ibnu Khaldun. (2001). Muqaddimah, Beirut: Dar Al-Fikr

Machmud, Amir. (2016). Perekonomian Indonesia Pasca Reformasi, Jakarta: Erlangga

Majalah Tabligh No. 4/ XIV, Mei (2016)

Nasir Omar, Mohd \& Muda Ismail Ab. Rahmah, (2015). Falsafah Ibnu Khaldun, Kuala Lumpur: Wisma ITBM

Nasrudin, dkk,. (2015). Dampak ACFTA terhadap kinerja perekonomian dan sektor pertanian Indonesia, Buletin Ilmiah Litbang Perdagangan, vol. 9 No. 1

Nopirin. (2013). Ekonomi Internasional, Yogyakarta: BPFE, 2013

Nugroho, Arief. (2018). Islamic Economic Thought Abu Ubaid (154224 H): Current Functions of Money and Relevance, Munich Personal RePEc Archive

Pertaminawati, Hendra. (2016). Anallisis Pemikiran Ibnu Khaldun tentang mekannisme pasar dan penetapan harga dalam perekonomian Islam, Kordinat, vol. XV No. 2

Putra Hartanto, Agas. (2019). Menaker: Kualitas SDM Tenaga Kerja Indonesia Rendah._di unduh pada 19 Desember 2019

Qadariyah, Lailatul, (2017). Buku Ajar Sejarah Pemikiran Ekonomi Islam, Jakarta:Duta Media Publishing

R Salam, Aziza dan Bagas Haryotejo. (2011). Dampak Ekonomi ASEAN China FTA terhadap produk elektronik Indonesia, Jurnal Standardisasi Vol. 13, No. 3

Rahmah Syahidah, Annisa, dkk,. (2016). Pengaruh ASEAN China Free Trade Area terhadap ekspor dan Impor Indonesia-China, Jurnal Administrasi Bisnis, Vol. 39, No. 1

Rizal, F. (2018). Relevansi Pemikiran Ekonomi Islam Abu Ubaid Dengan Perekonomian Modern. ACTIVA: Jurnal Ekonomi Syariah, 1(1), 110-129.

S, Junaidi dan Abdulmuhaimin. (2017). Analisis Perdagangan Pemikiran Ab u Ubaid Al Qasim dan Adam Smith mengenai Perdagangan Internasional, Millah; Jurnal Studi Agama, Vol. XVII, no. 1

Santoso, Singgih. (2015). Menguasai Statistik Parametrik konsep dan aplikasi dengan SPSS, Jakarta: Gramedia 
Setiawan, Sigit. (2012). ASEAN China FTA: Dampaknya terhadap ekspor Indonesia China, Buletin Ilmiah Litbang Perdagangan, Vol. 6, No. 2

Sheng, Yu dkk. (2012). The Impact of ACFTA on People's Republic of China-ASEAN Trade: Estimates Based on an Extended Gravity Model for Component Trade, $A D B$ Working Paper Series on Region Economic Integration, No. 99

Sjahril Sabaruddin, Sulthon. (2015). Indonesia terhadap kesejahteraan masyarakat: Aplikasi Structural Path Analysis, Buletin Ekonomi Moneter dan Perbankan, vol. 17, No. 4

Soedijono. (2004). Ekonomi Keuangan Internasional, Yogyakarta: UPP AMP YKPN

Sugiyono. (2016). Metode Penelitian Kombinasi (Mixed Methods), Bandung: Alfabeta cet ke-8

Sugiyono. (2017). Statistik untuk Penelitian, Bandung: Alfabeta

Suharto, Toto, (2020). Historiografi Ibnu Khaldun, JakartaKencana.

Sukirno, Sadono. (2015). Makroekonomi, Jakarta: PT. RajaGrafindo, cet ke-3

Ulum, Bahrul. (2016). Kontribusi Ibnu Khaldun terhadap perkembangan Ekonomi Islam, Jurnal Ekonomi Syariah Iqtishodia, vol. 1, No. 2

Wally, Salidin. (2018). Sejarah Pemikiran Ekonomi Islam Al Syaibani dan Abu Ubaid, Tahkim, vol. XIV, No. 1 